\title{
ERGONOMİK AÇIDAN İNSANIN TARİH ÖNCESİ VE SONRASI TEKNOLOJİLERİ İLE ÜRÜNLERINIIN KARȘILAŞTIRILMASI
}

\author{
Vahdet Özkoçak ${ }^{1 *}$, Galip Akın², Timur Gültekin³ \\ ${ }^{1}$ Hitit Üniversitesi Fen-Edebiyat Fakültesi, Antropoloji Bölümü, Fiziki Antropoloji ABD, İkbalkent-Çorum \\ ${ }^{2}$ Bozok Üniversitesi Fen Edebiyat Fakültesi, Arkeoloji Bölümü, Yozgat \\ ${ }^{3}$ Ankara Üniversitesi Dil ve Tarih Coğrafya Fakültesi, Antropoloji Bölümü, 06100, Sihhiye-Ankara
}

\begin{abstract}
Anahtar Kelimeler Özet
Paleolitik, İnsan yeryüzünde görülmesinden günümüze gelinceye kadar daima bir yaşam

Neolitik,

Ergonomi,

Alet,

Teknoloji. mücadelesi içinde olmuştur. Bu yaşam sürecinin 2,5 milyonunu zor ve çetin doğada, doğa koşullarında avcı-toplayıcı bir kültürle geçirmiştir. M.Ö. 10 bin yıl önce başlayan Neolitik dönemde ise sürtme taş tekniği ile yapılmış aletlerin yanında, kemik, boynuz ve dişten, ağaçtan ve kilden yapılmış alet, araç ve gereçler de vardır. Neolitik Dönemde günümüzde var olan, aşağı yukarı tüm teknolojilerin temeli ile bulaşıcı hastalıkların ve çevre kirlenmesinin başlaması hep bu dönemde olmuştur. Kalkolitik (M.Ö.5500-3000), Tunç Çağı (M.Ö.3000-1200) ve Demir Çağı (MÖ.1200 ve sonrasında) bakır, tunç ve demirden çeşitli aletler, fazla kas gücü harcanarak yapılır hale gelmiştir. Alet, araç, gereç, yapı, donanım ve yaşam alanlarının yapımı ve oluşturulması M.S.18.yüzyılın son çeyreğinde başlayan Sanayi Devrimi'ne kadar giderek çeşitlenmiş ve daha amaca uygun şekilde yapılabilmiştir. Sanayi Devrimi'yle birlikte fosil yakıtlarla çalışan makineler yapılmaya başlanarak, daha teknik, daha güçlü ve seri üretim yapılır hale gelmiştir. Ancak bu kadar bilgi, teknik ve teknoloji gelişmişsen ve her türlü ürün ergonomik kriterlere ve düzenlemelere göre rahatlıkla yapabilecek duruma gelmişken, insan birtakım çıkarlar ve rant uğruna hem kullanılan alet, araç, gereç ve makineleri hem de yapı, donanım ve yaşam alanlarını insan doğasına ve yapısına uygun olmayan şekilde yapmaya devam etmektedir.
\end{abstract}

$\mathrm{Bu}$ literatür çalışmasında, insanın yeryüzünde görülmesinden günümüze kadar süren serüveni örnekler verilerek tartışılacaktır.

\section{ERGONOMIC ASPECTS OF HUMAN HISTORY PRE-AND POST-COMPARISON OF TECHNOLOGIES AND PRODUCTS}

\author{
Vahdet Özkoçak ${ }^{1 \dagger}$, Galip Akın², Timur Gültekin ${ }^{3}$
}

${ }^{1}$ Hitit University, Faculty of Arts and Sciences, Department of Physical Anthropology, İkbalkent-Çorum. ${ }^{2}$ Ankara University Faculty of Language, History and Geography, Anthropology Department, Sihhiye-Ankara ${ }^{3}$ Bozok University Faculty of Arts and Sciences, Archaeology Department, Yozgat.

\begin{tabular}{ll}
\hline Keywords & Abstract \\
\hline Paleolithic, & The mankind has always been in a struggle for survival from the time they first \\
Neolithic, & seen on earth until today. The 2.5 million of this life cycle has been undergone as a \\
Ergonomics, & hunter-gatherer culture in hard and tough natural conditions. In addition to tools \\
Device, & made with ground stone technique in Neolithic period which begins B.C. 10 \\
Technology. & thousand years ago, tools which are made of bone, horn, the tooth, wood, and clay \\
\hline
\end{tabular}

\footnotetext{
*ilgili yazar: vahdetozkocak@hitit.edu.tr, +90-364- 227-70-01

${ }^{\dagger}$ Corresponding Author: vahdetozkocak@hitit.edu.tr, +90-364- 227-70-01
} 
are also available. The roots of almost all the technology and occurring of infectious diseases and environmental pollution which we also have today existed in Neolithic Period. Various Tools such as copper, bronze, and iron become available by exerting muscle power during Chalcolithic Age (B.C. Between 55003000 years), Bronzezeit Age (B.C. between 3000-1200 years) and Iron Age (B. C. 1200 and after). Constructing and forming of appliances, tools, equipment, structures, and habitats for people until to the Industrial (which is in the last quarter of 18 century) Revolution increasingly diversified and could be made in accordance for purpose. Beginning with the Industrial Revolution, machines that operate with fossil fuels were made, and therefore more technical, more powerful and mass production became doable. However, even if this knowledge, techniques and technology flourished and all kinds of products easily made in accordance with the ergonomic criteria and regulations, people continues to produce and contracture both used tools, vehicles, equipment and machinery as well as buildings, equipment and habitat in a way that is improper to the human nature and structure for the sake of some interests and benefits. In this study, which is realized using literature search technique, the adventure of people from the time they first seen on earth to today is discussed by giving samples.

\section{Giris}

İnsan yeryüzünde görüldüğü yaklaşık 2.5 milyon yıl öncesinden itibaren, doğada ve doğa koşullarında avcl-toplayıcı kültürle yaşamını sürdürmeye başlamıştır. Doğada ve doğa koşullarında yaşam zor ve çetin olduğundan, bu süreçte insan yaşamı daha da güçleşerek yok olma tehlikesiyle bile karşı karşıya kalmıștır. Çünkü insan, hammaddesi doğada bulunan maddelerden yararlanarak alet, araç-gereç, makine, yapı, donanım ve yaşam alanlarını oluşturarak yaşam kalitesini belirler. Yapılan her türlü ürün ne kadar amaca, insan boyutlarma ve teknolojiye uygunsa, bu ürün o oranda, insan yaşamını kolaylaştırarak, yaşam kalitesini de arttırır. Amaca, insan boyutlarına ve teknolojiye uygun ürün yapabilmenin koşulu, bilgi birikimine, yeteneğe, deneyime ve ortam koşullarına bağlıdır. Ayrıca alet yapabilmenin, sinir, kas, iskelet ve duyu organlarının hassas ve koordinasyon içinde çalışmasıyla mümkün olabildiğini de unutmamız gerekir (Braidwood, 2008; Akın,2011).

İnsan, hammaddesi doğada bulunan herhangi bir maddeyi şu ya da bu şekilde değiştirerek, onu amaca yönelik bir şekil vererek, yeni biçimiyle ondan yararlanan, dünyada tek canlı türüdür. Alet, makine, yapı, donanım ona gereksinim duyana, onsuz yapmasına imkân olmayana lazımdır. Örneğin, günümüzde bir bilgisayarı kullanmasını bilmeyen bir kişi için, bilgisayar bir alet veya araç değildir. İnsan dünyanın neresinde ve hangi ekolojik ortam içinde olursa olsun alet yapmıștır. Bu sayede insan kutup bölgeleri hariç dünyanın her bölgesinde yaşayabilmektedir. Kimi bilim insanları "İnsan aletsiz bir hiçtir. İnsanın insanlaşmasında, yaşamını sürdürmesinde ve doğada bugünkü bulunduğu yere ulaşmasında her şeyini yaptığı aletlere borçludur" denmektedir. Gerçekten insan, yeryüzünde kültüre sahip tek canlısı olması, onu diğer canlılardan ayıran en önemli özelliğidir. İnsanın aletsiz yaşamını sürdürmesine olanak yoktur. Bugün bir an için çevremizde, evde, işyerlerinde kullandığımız veya yararlandığımız alet ve her türlü ürünü yok farz ederek, yaşamaya çalıştığımızda alet ve ürünlerin yașam için önemini ve değerini daha iyi anlayabiliriz. Örneğin, kaşıksız bir çorbayı içmenin, gözleri miyop

veya hipermetrop olan bir kişinin gözlüksüz okumasının imkânsızlı̆̆ını, araçsız bir şehirden diğer şehre gitmenin güçlüğünü hepimiz anlayabiliriz (Karul, 2011; Sagona and Zimansky, 2015).

Üretilen her ürün, onu kullanan veya yararlananın ihtiyacına, amacına ve çevre koşullarına uyumunu sağlayacak nitelikte olmalıdır. Bir ürün, yapılmış olsun diye yapılmaz. Bu nedenle ihtiyaç, yeni ürünlerin yapılmasını tetikler. Bir ürün onu kullanan veya yararlananın amacına uygun iş yapmasına yardımcı olmalıdır. Günümüzde üretilen bir ürünün amacına uygun, yani işlevsel, ürünü kullanan veya yararlananın özelliklerine göre tasarlanıp üretilebilmesi için Ergonomi biliminden yararlanılmaktadır. Bir ürün ancak Ergonomik kriterlere göre üretilirse işlevsel olabilir. Ergonomi bir yandan insanın doğal yeteneklerinin sınırlarını genişletmeye çalışırken, diğer yandan da insanmakine sisteminin performansını artırmayı amaç edinir (Akın, 2013; Sabancı ve Sümer, 2011).

$\mathrm{Bu}$ derleme çalışmasında, insanın yeryüzünde görülmeye başlamasından günümüze gelinceye kadar, her türlü alet ve ürün gelişimini kronolojik düzen içerisinde verilerek, insan yaşamına sağladığı yararlar ve yaşam kalitesi artışına etkisi vurgulanarak açıklanacaktır.

\section{2. İlk Alet Yapımı ve Gelişim Süreci İle Yașam Alanları}


İlk insan türleri olarak bilinen Homo habilis ile Homo rudolfensis'in Afrika'da Rift Vadisi'nde başlayan serüveni, zaman içinde ortam şartlarının değişmesine bağlı olarak güçleşmiş, bazen de iyileşmiştir. İnsan kültürü sayesinde zaman içinde karşılaştı̆̆ güçlüklerle baş edebilmiştir. İnsan evrimsel süreçte, sahip olduğu kültürü, ihtiyaç duyduğu alet ve diğer ürünleri bilgi düzeyi, yeteneği ve deneyimi oranında, daha amaca uygun daha teknolojik ürünler haline getirmiştir (Akın, 2011).

İlk insan türlerinden olan Homo habilis ve Homo rudolfensis, Olduvan kültürü olarak bilinen ve oldukça basit Çaytaşı aletlerini (Tablo 1) yaparak avcl-toplayıcı olarak Afrika'da Rift Vadisi ve civarında zor doğa koşullarında yaşamışlardır. Rift Vadisi ve çevresinde iklimin kuraklaşması yaşamı güçleştirdiğinden, M.Ö.1.800.000 ile 1.900.000 yll öncesinde Afrika dışına göç başlamıştır. Afrika dışına göç eden Homo erectus, Acheuliyen (El Baltası) kültürüne sahip olarak Afrika'nın güney ve kuzeyine yavaş yavaş hareket ederek, kuzeyde Mısır üzerinden İsrail, Ürdün ve Suriye vasıtasıyla, yaklaşık 1.2 milyon yılda Anadolu'ya ulaşmıştır. Oradan Avrupa'ya kadar uzanmışlardır. Diğer bir kolda Ürdün, Irak, İran ve Karadeniz üzerinden Avrupa'ya ve ayrıca İran üzerinden Çin'e 1.1 milyon yll önce, Güney Asya adalarına günümüzden 1 milyon yıl önce ulaşmıştır. Alt Paleolitik 2.5 milyon yıl öncesinde başlayıp yaklaşık 130 milyon yll öncesine kadar devam etmiştir (Karul, 2011; Sagona and Zimonsky, 2015).

Tablo 1. Geçmişten Günümüze Alet Teknolojisi (Larsen, 2016).

\begin{tabular}{|c|c|c|c|}
\hline Hominid & $\begin{array}{l}\text { Kullandığı } \\
\text { Alet }\end{array}$ & $\begin{array}{l}\text { Alet } \\
\text { Özellikler } \\
\text { i }\end{array}$ & Örnek \\
\hline $\begin{array}{l}\text { Homo } \\
\text { habilis } \\
(2.5-2 \text { my) }\end{array}$ & Çakmak taşı & $\begin{array}{l}\text { Yontuk } \\
\text { çakıllar, } \\
\text { kazıcı } \\
\text { aletler }\end{array}$ & \\
\hline $\begin{array}{l}\text { Homo } \\
\text { erectus/er } \\
\text { gaster (1.8- } \\
500 \quad \text { bin } \\
\text { yll) }\end{array}$ & $\begin{array}{l}\text { Aşölyen + } \\
\text { Çakmak taşı }\end{array}$ & $\begin{array}{l}\text { İki } \\
\text { yüzeyliler } \\
+\quad \text { El } \\
\text { baltaları }\end{array}$ & \\
\hline
\end{tabular}

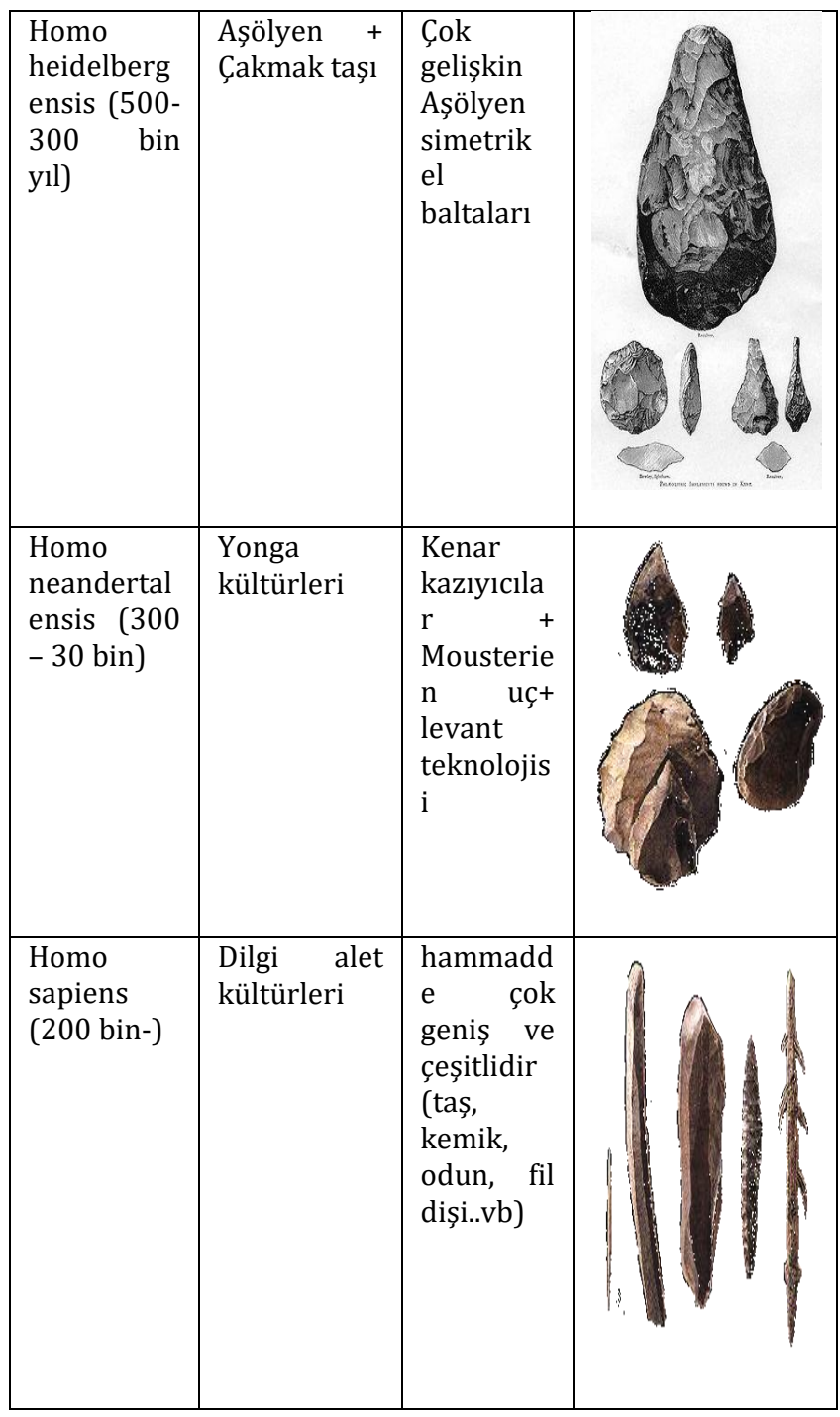

Günümüzden yine yaklaşık 400.000 yll önce başlayıp 40.000 yll öncesine kadar Homo sapiens arkaikler ve 130 bin yıl önce ortaya çıkıp 40.000 yıl öncesinde yok olan Homo neanderthaller ise Musteriyen (Yonga aletler) (Tablo 1) kültürüne sahip olmuşlardır. 40 bin yıl önce başlayıp M.Ö.12.000 yıla kadar ise Üst Paleolitik devam eder. Üst Paleolitik' te sırasıyla Aurignasiyen, Gravetiyen, Solutriyen ve Mağdeleniyen taș kültürleri ortaya çıkar. Bunlara genel olarak "Dilgi” aletler denir. Üst Paleolitik' te taş aletler, çeşitlenmeye ve daha detaylı aletler haline geldikleri görülür. $\mathrm{Bu}$ dönemde yapılan aletlerin tamamı çakmak taşından, obsidiyenden ve benzeri tașlardan yapılmıștır. Homo sapiens'lerin aletleri, ilk olarak 100.000 yıl önce başlayıp günümüze kadar gelir. M.Ö. 40 bin öncesinden itibaren balıkçllık yapmaya başlamaları ve daha sonra zıpkının icat edilmesiyle, deniz ürünleri diyet menüsüne dahil olur (Braidwood, 2008; Bogucki,2013).

M.Ö. 12 bin yll öncede Mezolitik Dönem'in bașlamasıyla çakmak tașından veya obsidiyenden "Dilgi" aletler yapılmaya devam eder (Tablo 1). 
İnsanın yeryüzünde görülmesinden, Paleolitik Dönem boyunca taş aletler dișında bir alet yapmadı̆̆ söylenemez. İnsan bu dönemlerde de ağaçtan, kemikten, boynuzdan, dişten aletler yapmıștır. Ancak aradan yüz bin, hatta milyon yıl geçtiği için ve bu dönemlerde avcı-toplayıcı olduklarından, yaptıkları bu aletler fosilleşmeden çürüyerek yok olmuşlardır (Erek ve ark, 2015).

M.Ö. 9-10 bin yıl içerisinde devrim niteliğinde sayılan Neolitik Dönem bașlar. Bu dönemde yerleșik düzene geçilir. Sonuçta ilk kez tarım yapılarak buğday, arpa çavdar, mercimek ehlileştirilmeye, hayvancılıkla ise domuz, koyun, keçi ve tavuk ehlileştirilerek yetiştirilmeye başlanır. $\mathrm{Bu}$ dönemin ortalarında M.Ö.7.500 yıllarında ilk kez çanak çömlek yapılmaya başlanır. Bu dönemde Sürtmetaş aletleri görmekteyiz. Sürtmetaş aletler, taşların birbirine sürtülerek pürüzlerinin giderilmesi sonucu elde edilen aletlerdir. Bugün toplumların ulaştığı yaşam biçiminden, teknolojik aletlere ve çevre kirlenmesine kadar olumlu veya olumsuz her şeyin temeli Neolitik Dönem' de atılmıştır diyebiliriz (Bellwood, 2008).

M.Ö. 5500- 5000 yllarından itibaren Madenler Dönemi başlar. İlk olarak bakır madeninden bakır elde edilerek, taş aletlerin yanı sıra bakırdan kaplar ve kesici aletler yapılır. Ayrıca şehir devletlerinin temeli atılarak, şehirlerin etrafı surlarla çevrilir. Saldırılara karşı korunmak için yapılan surların içinde belli bir plana göre yapılaşma görülür. M.Ö.3000 yıllarında Kalkolitik Dönem' in sonuna doğru yazı icat edilir. Yazının icadıyla Tarih Öncesi Dönemler sona ererek Tarihi Dönemler başlar (Kiple, 2010; Karul, 2011).

Kalkolitikte, özellikle bu dönemin sonlarına doğru bir yerleşim alanında, yerleșim alanının özelliğine ve çevrede bulunan hammaddelere göre insanlar, basit meskenlerde yaşamalarının ardından, Mezopotamya'da site devletlerini oluşturma hazırlıklarını görmekteyiz (M.Ö.6000'li yıllarda) (Bellwood, 2008).

M.Ö.5500-3000 yılları arasında devam eden Kalkolitik Dönem' de site devletleri oluşmuş, başta kral, yöneticiler, din adamları, askerler, çiftçiler, çobanlar, esnaf ve zanaatkârlar gibi meslekler ortaya çlkmak suretiyle toplum içinde katmanlaşma başlamıştır. Bu yerleşim yerlerinin etrafı surlarla çevrilmiştir (Köroğlu, 2013; Akın ve ark, 2015).

M.Ö.3000'li yıllarda bakırla kalayın karıștırılmasıyla elde edilen tunç sayesinde, daha sert metal aletler ve silahlar yapılabildiğinden bu çağa, Tunç Dönemi denilmiştir. Tunç Döneminde yapılan metal alet ve benzerlerinin daha fazla çeşitlendiğini, daha teknik özelliklere sahip olduğunu görüyoruz. Site devletlerinde yapılan eşya ve evler de dayanıklı ve belli bir düzene göre yapılmıștır. Öte yandan Tunç Dönemi'nin başlarında gerçek anlamda yazı icat edilerek, önemli olaylar ve bilgiler kayıt altına alınmış ve bunlara daha fazla kişinin bilmesi ve gelecek nesillere ulaşması mümkün hale gelmiştir (Kremer, 1998; Nissen, 2015).

Tarihi dönemlerin başlamasıyla, nesilden nesile sözlü olarak aktarılan bilgiler yazıya dökülerek kalıcı hale geldi. Bilgi, yetenek ve deneyimler arttıkça yaşamı kolaylaştıran alet taştan, ağaçtan, kemikten, boynuzdan, dișten ve madenlerden daha işlevsel olarak art arda üretilmeye başlar. Ancak seri üretime, M.S.18.yüzyılın son çeyreğinde başlayan Sanayi Devrimi'ne kadar geçilememiştir (Kramer, 1998; Koroğlu, 2013). Bakırla kalayın eritilmesiyle elde edilen, daha sert bir alaşım olan tunç ile kaba da olsa her çeşit alet ve benzeri ürünler yapılır hale geldi. M.Ö.3000 yıllarında başlayan Tunç Devri, M.Ö.1200 yılında başlayan Demir Devri'ne kadar devam etti. Daha dayanıklı kılıç, balta, kalkan, mızrak ve ok uçları yapılırken çanak, çömlek gibi mutfak ve ev aletleriyle, sağlam sur kapıları yapılır hale geldi. Saban, orak gibi ziraat aletleri tunçtan yapılmaya başlandı (Karul, 2011; Sagona and Zimonsky, 2015). M.Ö.1200 yılında demir cevherinden demirin elde edilmesi, dayanıklı alet yapımında demirin tercih edilmesine neden olmuştur.

\section{Anadolu'da İnsan ve Kültürü}

Anadolu kronolojisine bakıldığında (Tablo 2), Tunç Dönemi ve sonrasında Mezopotamya, Bereketli Hilal ve Anadolu'da birçok beylik, krallı ve imparatorluklar kurulmuştur.

Tablo 2. Anadolu kronolojisi (Akurgal, 2007; Zimonsky and Sagona, 2015).

\begin{tabular}{|l|l|}
\hline \multicolumn{1}{|c|}{ Dönem } & \multicolumn{1}{c|}{ Tarih } \\
\hline Erken Neolitik & $9000-6000$ M.Ö. \\
\hline Geç Neolitik & $6000-5000$ M.Ö. \\
\hline Erken Kalkolitik & $5000-4500$ M.Ö. \\
\hline Geç Kalkolitik & $4500-3000$ M.Ö. \\
\hline Erken Bronz & $3000-2000$ M.Ö. \\
\hline Orta Bronz & $2000-1200$ M.Ö. \\
\hline Geç Bronz & $1200-1000$ M.Ö. \\
\hline Erken Demir & $1000-860$ M.Ö. \\
\hline Demir & $860-580$ M.Ö. \\
\hline Helenistik & $333-30$ M.Ö. \\
\hline Roma İmparatorluğu & $30-395$ M.S. \\
\hline $\begin{array}{l}\text { Doğu Roma (Bizans) } \\
\text { İmparatorluğu }\end{array}$ & $395-1453$ M.S. \\
\hline A. Selçuklu İmparatorluğu & $1074-1308$ M.S. \\
\hline Osmanlı İmparatorluğu & $1299-1923$ M.S. \\
\hline
\end{tabular}

Günümüze kadar gelen, bilgi, kanıt ve belgilere göre Anadolu'da ilk insanın görülmesinin tarihi 
M.Ö.1.200.000 ylla kadar gidebilmektedir. Bu insanlar yerleşik düzene geçişin başladı̆̆ı Neolitik Dönem başlangıcına kadar (M.Ö.10.000 yıl öncesi) daima avcı toplayıcı bir kültürle 25-30 kişilik gruplar halinde zor koşullar altında yaşamlarını sürdürmüşlerdir. Neolitik Dönem' e kadar avcı-toplayıcı kültürle yaşadıkları için sürekli av ve bitkilerin meyve ve tohumlarının olgunlaşma zamanlarını takip ederek hareket halinde olduklarından, çaytaşı, çakmaktaşı, obsidiyen gibi kaya parçalarından basit taş aletler yaparak geçirmișleridir (Karul, 2011; Bogucki, 2013).

Neolitik Dönem öncesinde insanlar ağaç, kemik, diş ve boynuzdan da aletler yapmişlardır. Ancak çürümeden kalan ve elimize geçen bu tip aletler, Üst Paleotik (M.Ö. 40.000 - M.Ö. 12.000 yılları arası) döneme ait zıpkın, kemik iğne, bız, deniz kabuklarından süsler ve oklardır (Braidwood, 2008; Karul, 2011; Sagona and Zimansky, 2015).

İnsanın yerleşik düzene geçmesiyle beraber, basit de olsa ağaç ve taştan evler yapılmaya başlanmış ve ev için gerekli olan aletler, ağaçtan, kemikten (orak gibi), boynuz ve kemik ile taştan (sürtme taşı, el değirmeni) çeşitli amaçlara uygun aletler ve eşyalar yapmaya başlamışlardır. Diğer bir anlatımla, hem alet ve diğer eşyalar çeşitlenmiş, hem de sürtme taş tekniği ile alet ve eşyalar pürüzsüz hale getirilmiştir (Karul, 2011; Sagona and Zimonsky, 2015).

Kalkolitik Dönemden (M.Ö. 5500-3000) itibaren bakır madeni eritilerek birçok alet ve eşyanın yapılmasıyla yavaş yavaş gerekli eşyalar bakırdan da yapılmaya başlanmıştır. Özellikle Tunç Dönemi'nde, tunçtan aletlerin yapılması alet ve eşya yapımını artırdığı gibi, eşya çeşitliliğinin de artmasına neden olmuştur. Ayrıca, şehirlerin etrafını çevreleyen surlar ve şehre giriş çıkış kapıları ve taştan yapılan evler belirli bir plana, savunmaya uygun ve sağlam yapılar halinde inşa edilmeye başlamıştır. Bunları, Hitit ve Urartu imparatorluklarının, Frigler ile Persler' in Anadolu'da yaptıkları eserler ve kalıntılarından anlayabiliyoruz. Örneğin, Ankara'daki Anadolu Medeniyetler Müzesi'nde hemen her çeşit alet ve yapıları kronolojik sıraya uygun görmek mümkündür. Öyle ki, Frigya Kralı Midas'ın mezarında, sarayına ait tahtadan yapılmış masa şeklindeki mobilya hala orijinal halde ve insan yapısına uygun yapılmıș olarak bulunmuştur (Akurgal, 2007; Brandau and Schicert, 2011).

Anadolu Selçuklu Dönemi (M.S.1071-1308) ve Osmanlı İmparatorluğu (M.S. 1299-1923) Dönemi'nde, yapılan aletlerin ve yapıların her birinin işlevsel ve planlı olarak yapıldıklarını rahatlıkla söyleyebiliriz. Anadolu Selçuklu Devleti ve Osmanlı İmparatorluğu Dönemleri' ne ait alet ve yapı örneklerini Anadolu'nun her tarafında görmek ve incelemek mümkün olur.
$\mathrm{Bu}$ konuda açıklıkla söyleyebileceğimiz, kazı ve araştırmalarda ele geçen her türlü alet ve yapıların saraylara, yüksek sosyoekonomik düzeye, o döneme göre çok varlıklı kişilere ait olduğu gerçeği unutulmamalıdır. $\mathrm{Bu}$ dönemlerde halkın çoğu yoksulluk içindedir diyebiliriz.

\section{Sanayi Devrimi Sonrası}

Neolitikle birlikte insanın besin üretimine geçișiyle, besinleri kurutma, tütsüleme, tuzlama, kavurma, salamura yöntemlerini de öğrenerek, besininin az veya olmadığı dönemlerde kullanmak için saklayarak yaşamını garanti altına almıştır. Böylece insan düşünmeye, sorunlarını çözmeye ve yeni gerekli aletleri ve yapıları yapabilecek teknikleri araştırmaya ve bulmaya zaman bulabilmiştir. Çünkü düşünen, gören, anlayan, araştıran insan, sorunlarını tespit ederek çözüm yolları bulabilir veya çözüm geliştirebilir. Bu şekilde her geçen gün, bilgi birikimi, deneyimi, yeteneği arttıkça gereksinimlerini cevap verebilecek yeni alet, araç-gereç, yapı, donanım ve yaşam alanları yapabilecek hale gelmiștir (Kiple, 2010; Akın ve Gültekin, 2015).

İnsan ilk çağlardan beri bilinçli ya da öğrenmek suretiyle kendine yararl besinleri seçerek Neolitikten itibaren üretebilmiş, bilgi biriktirmiş, yeteneği ve deneyimi oranında alet ve diğer gereksinimlerini yapabilmiştir. Yukarıda kısaca açıklanan tarih öncesi ve tarihi dönemlerde, insan basitten giderek artan sayıda, teknikte, kaliteli işlevsel diyebileceğimiz alet ve yapı, donanım gibi gereksinimlerini yapmıştır. Beyin kapasitesinin elverdiği oranda korunabileceği, daha çok yararlanabileceği yerleri seçmeye çalıșmış, böylece, daha amaca uygun alet ve diğer ihtiyaçlarını yapma firsatı bulabilmiştir. Bütün bunlar insanın gerçekleştirdiği ergonomik tercihlerdir (Akın, 2013).

İnsan, 18. yüzyılın son çeyreğinde bașlayan Sanayi Devrimi'ne kadar, makineleşmeye ve seri üretime geçememiştir. Her türlü alet ve benzeri ürünler ile yapı, donanım ve yaşam alanlarını basit aletler kullanarak, fazla kas gücü ve zaman harcayarak yapabilmiștir. Sanayi Devrimi'yle yavaș yavaș makineleşme ve seri üretime geçmiştir. Ancak İkinci Dünya Savaşı'na kadar üretilen makine ve her türlü yapı ve donanımlar, sadece talebi karşılayabilmek amacıyla üretilmişlerdir. Bunları kullanacak ve yararlanacak olanın insan olduğu gerçeği unutulmuş veya dikkate alınmamıștır. Hâlbuki her türlü ürünü yapanın da onu kullanan ve yararlananın da insan olduğu, yapılan ürünlerin insan yaşamını kolaylaştırmak ve az yorulmak, daha az enerji harcamak için ürünlerin yapıldığı, gözardı edilmiştir. 
İkinci Dünya Savaşı öncesine kadar yapılacak her ürünün daha yararlı ve insan yaşamını kolaylaştırmak için olduğu bilinerek bazı aletler ve makineler üretilmişse de, bu tip çalışmalar başlangıç ve basit düzeyde, genellikle de bireysel çalışmalardır (Sabancl ve Sümer, 2011; Akın, 2013).

İkinci Dünya Savaşı sonrasında başta savaş sanayinde olmak üzere, tüm sanayi kollarında insanın yaptığı her ürünün, onu kullanan ve yararlananın morfolojik, anatomik, fizyoloji ve ruhsal yapı ve kapasitesine uygunluğu, yani Ergonomik kriterlere ve düzenlemelere göre yapılan ürünlerin sanayisi, gelişmiş ülkelerde yapılmasına karşın, gelişmekte olan ve az gelişmiş ülkelerde çoğunlukla göz ardı edilmiştir (Zander, 1996; Akın ve ark, 2015).

Günümüzde, her türlü ürünün Antropometrik, işlevsellik, teknolojiklik, estetiklik, orijinallik ve ekonomiklik gibi Ergonomik kriterlerine, ayrıca ișyeri ve yaşam alanlarının Antropometrik, psikolojik, fizyolojik, enformasyon tekniği ve iş emniyeti açılarından Ergonomik düzenlemelerin yapılması gerektiği bilimsel olarak bilinmesine rağmen dünyada çoğunlukla Ergonomik kriterler ve düzenlemeler dikkate alınmadan yapıldığı izlenimi vermektedir. Çünkü özellikle az gelişmiş ve gelişmekte olan ülkeler olmak üzere dünyada her geçen yıl işçi sağlığı ve verimliliği, öte yandan üretim artışı gözardı edilerek üretim yapılmasından dolayı, milyonlarca iş kazası, verim düşüşü halen daha çok yüksek düzeydedir. Esasen Ergonomik kriterlere ve düzenlemelere göre üretim yapılan her yerde hem iș kazası daha az ve verimlilik daha fazla olduğu gibi hem de yaşam kalitesi yüksek olur (Akın ve Gültekin, 2015).

Ergonomik olarak üretilmeyen bir ayakkabının, bir sıranın, bir apartmanın, bir kent parkının ne gibi sıkıntılar yarattığını hepimiz biliriz. Kentlerde 15-20 yıl önceden başlayan 20-30 hatta 100 kattan daha fazla olan binaların arsa sıkıntısı bahane edilerek yapıldığını görüyoruz. Bu șekilde çok katlı binaların insan doğasına aykırı olduğu biliniyor, ama bunların yapımı hala hızla devam ediyor. Yeterli düzeyde kent parkları, dinlenme ve eğlence alanları özellikle büyük kentlerde yapılmiyor. Ayrıca kentlerdeki bebek, çocuk, yaşl, hasta ve özürlülerin erişkinlerden fazla olduğu bilindiği halde, bunlar bilmezlikten gelinerek, çıkar veya rant uğruna, hatalı ve insan doğasına uymayan kentleşmelere devam edilmesi, insan aklına sığdırılamayacak kadar anormalliktir (Zander, 1996; Gönen ve Özden; Akın, 2010).

\section{Sonuç}

İnsanın yeryüzünde görülmesiyle doğa ve doğa koşullarıyla da yaşam mücadelesi başlamıştır.
Doğanın ve çevresel koşulların durumuna ve insanın birikimine, yeteneği ve deneyimine bağlı olarak yaşamını sürdürmüştür. Öyle ki bazen doğa ve çevre koşulları nedeniyle yok olma tehlikesiyle bile karşı karşıya kalmıştır. İnsan 2.5 milyon yıl öncesinde yeryüzünde görülmesinden Milattan 10 bin yıl önce Neolitik Dönem' in başlangıcına kadar tamamen doğa koşullarında avcı ve toplayıcı kültüre sahip olarak, basit, daha kaba ve çok amaçlı taştan aletler yaparak (genelde çaytaşı, çakmaktaşı ve obsidiyenden) zor koșullarda yaşamıștır.

İnsanın Neolitik Dönem'den itibaren ilk kez hayvan ve bitkileri evcilleștirerek besin üreticisi durumuna gelmesi, devrim niteliğinde bir olay olmuştur. Çünkü insan, uygun zamanlarda elde ettiği besinleri çeşitli saklama yöntemleri geliştirerek, besin saklamayı başardıklarından, uygun olmayan zamanlarda bu besinlerle beslenerek yaşamlarını sürdürmüşlerdir. Böylece düşünmeye, anlamaya, görmeye ve araştırmaya zaman bularak ihtiyaç duydukları alet, araç-gereç gibi ihtiyaçlarını yapmaya, üretmeye ve sorunlarına çözüm bulmaya başlamışlardır.

Kalkolitik, Tunç, Demir Çağı ve Sanayi Devrimi'ne kadar artan miktarlarda ve daha ișlevsel ve de kaliteli ürünleri güç ve daha fazla zaman harcayarak, madenlerden, ağaçtan, kemikten, boynuzdan, dișten, yaşamlarını kolaylaştırıcı alet ve benzeri ürünler yapmışlardır.

18. yüzyılın son çeyreğinden itibaren başlayan Sanayi Devrimi'yle birlikte alet, araç ve gereçlerin yanında seri üretim yapan makineler üretilmeye başlanmıştır. Günümüze gelindikçe daha ișlevsel, teknik ve daha güçlü makine, donanım ve yapılar yapılmıştır. Günümüz elektronik, mikroçip, bilgisayar devri olarak nitelendirilmektedir.

Gelişmiş ülkeler her türlü ürünü genelde Ergonomik kriterler ve düzenlemelere göre yaparken, gelișmekte ve az gelişmiş ülkelerde ise genellikle ergonomik kriter ve düzenlemeler göz ardı edilerek üretim yapılmaktadır. Ancak gelişmiş ve az gelişmiş ülkelerde, kentlerde insan doğasına uygun olmayan 20-30 ve daha fazla katlı binalar yapılarak, yeterince kent parkları, eğlence ve dinlenme alanları için yer ayrılmadan kentler beton yığınlarına dönüştürülmektedir. Öyle ki çocukların oynayabileceği, insanların sosyal aktivitelerini rahatlıkla yapabilecekleri alanları bulmak, görmek zorlaşmaktadır. Şehirde erişkinlerden fazla bebek, çocuk, yaşlı, hasta ve özürlülerin bulunduğu hatırlanarak, rant kaygısı olmadan ve insanların sosyal bir varlık olduğu daima göz önünde bulundurularak, Ergonomi bilimi çerçevesinde tasarımlar yaparak, üretim yapmamız gerektiği bilinciyle hareket etmeliyiz. 
İnsanın geçmişten günümüze her türlü zorluğu ve tehlikeyi aklı ve sağduyusu sayesinde yenme azminde ve gücünde olduğunu bilmeliyiz. İnsan yeter $\mathrm{ki}$ istesin. Tarihte bununla ilgili birçok örnek bulabiliriz.

\section{Conflict of Interest / Çıkar Çatışması}

Yazarlar tarafından herhangi bir çıkar çatışması beyan edilmemiştir.

No conflict of interest was declared by the authors.

\section{KAYNAKÇA}

Akın, G. 2011, Antropoloji ve Antropoloji Tarihi, Tiydem Yayıncllk, Ankara.

Akın, G. 2013, Ergonomi, Alter Yay. Rek. Org. Tic. Ltd. Şti, Ankara.

Akın, G; Gültekin, T. 2015, Ergonomik Restoran Tasarımı ve Güvenliği, Ankara Üniversitesi Beypazarı Meslek Yüksekokulu, Yayın No 2, Ankara.

Akın, G, 2010, Yaşam kalitesinin artırılmasında Antropometrinin önemi, 9. Ulusal Biyolojik Antropoloji Sempozyumu, 04-06 Kasım 2010, Ankara.

Akın, G; Gültekin, T; Özkoçak, V, 2015, Geçmişten günümüze geleneksel Anadolu Mutfak Kültürünün gelişimi, Antropoloji Dergisi, Sayı: 30, S:33-53.

Akurgal, E. 2007, Anadolu Uygarlıkları, Net Turistik Yayınları A.Ş, İstanbul.

Bellwood, P, 2008, First Farmers (The Origin of Agricultural Societies), Blackwell, Publishing, USA.

Brandau, B. And Schickert, H. 2011, Hititler, Bilinmeyen Bir Dünya İmparatorluğu, Çeviren: Nazife Mertoğlu, Arkadaş Yayınevi, Ankara.

Bogucki, P. 2013, İnsan Toplumunun Kökenleri, Çeviren: Cumhur Atay, Kalkedon Yayınları: 233, Arkeoloji Dizisi: 1, İstanbul.

Braidwood, R. J. 2008, Tarih Öncesi İnsanlarl, Çeviren; Bilgi Altınok, Arkeoloji ve Sanat Yayınları, İstanbul.

Erek, C.M; Arbuckle, B; Atakuman, Ç; Özçelik, K; 2016. Anadolu Prehistorya Araștırmaları Dergisi 1, Bilgin Kültür Sanat Yayınları, Ankara.

Gönen, E; Özgen, Ö, 1995, Çevre, yașam kalitesi ve Ergonomi, 5. Ergonomi Kongresi, Milli Prodüktivite Merkezi Yayınları, No: 570, S.280289, İstanbul.
Karul, N, 2011, Tarih Öncesinden Demir Çă̆ına Anadolu'nun Arkeoloji Atlası, Doğan Burda Dergi Yayıncllık ve Pazarlama A.Ş., İstanbul.

Kiple, K. F. 2010, Gezgin Şölen, Gida Küreselleşmesinin On Bin Yıll, Çeviren: Nurettin Elhuseyni, Yapı Kredi Yayınları; 3175, İstanbul.

Köroğlu, K, 2013, Eski Mezopotamya Tarihi, İletişim Yayınları: 1136, Başvuru Dizisi No:46, İstanbul.

Kramer, S.N, 1998, Tarih Sümer'de Başlar Çeviren: Muazzez İlmiye Çı̆̆ , Türk Tarih Kurumu Basımevi, Ankara.

Larsen, S.P 2016 Essentials of Physical Anthropology: Discovering Our Origins, Third Edition. W.W. Norton, New York. 479 pp.

Nissen, H.J, 2015, Ana Hatlariyla Mezopotamya, Arkeoloji Yayınları, Deneme, Eleştiri Dizisi: 29, İstanbul.

Sabancl, A; Sümer, S, K, 2011, Ergonomi, Nobel Akademik Yayıncılık, Eğitim Danışmanlık, Tic. Ltd. Şti. Ankara.

Sagona, A; Zimansky, P. 2015, Arkeolojik Veriler Ișığında Türkiye'nin En Eski Kültürleri, MÖ 1.000.000-550, Çeviri Kurulu: Nezih Başgelen, Sim İris Belik, Margaret Payne, Harun Taşkıran, Arkeoloji ve Sanat Yayınları, 2015.

Zander, J. 1996, Ergonominin Temel İlkeleri, Çeviren: Alaettin Sabancl, Çukurova Üniversitesi Ziraat Fakültesi Genel Yayın No:142, Adana. 